\title{
Evaluation of Perception and Performance in ICT Related Courses
}

\author{
Annie O. EGWALI \\ Department of Computer Science, \\ University of Benin, Benin City. \\ Nigeria.
}

\author{
Efosa C. IGODAN \\ Department of Computer Science, \\ University of Benin, Benin City. \\ Nigeria.
}

\begin{abstract}
Some teaching methods adopted for disseminating Information Communication Technology Related Courses (ICTRC) in institutions of learning have been observed to be inadequate in bringing about the right perception and performance in students. In order to qualitatively establish the efficiency of tutoring ICTRC, this study investigates the effect of ICT resources on students' perception and performance in ICTRC. Two hundred and forty-eight (248) students in the Department of Computer Science/ICT from two universities: a Federal and a Private University from the South-South region of Nigeria were used. A pre-test, post-test control group and quasi experimental design were utilized. Findings revealed that teaching ICTRC without using ICT resources are not effective at empowering the students with the right perception and the students are not enabled to perform to the best of their ability. Some recommendations are proffered encouraging ICT aided teaching strategies in Nigeria.
\end{abstract}

Keywords- Learning, ICT, Education, Perception, Performance, Examination.

\section{INTRODUCTION}

According to [1], Information Communication Technology (ICT) is the acquisition, dissemination, processing and storage of numerical, vocal, textual and pictorial information by a microelectronics-based combination of computing and telecommunications. ICT plays a dominant role in our present environment enabling humans to understand the increasingly technological changing society. ICT provides learners with understanding, skills and scientific knowledge needed for scientific research, fostering technological and economic growth in the society, where they live thus improving the standards of living [9]. ICT enables learners to acquire problem-solving and decision-making skills that provides ways of thinking and inquiry which helps in radical changes.

With the rapid usage of ICT resources (i.e. internet), ICT based teaching-learning applications are considered an effective alternative to traditional teaching methods in that it affords students unlimited opportunities to demonstrate mastery of contents taught [6]. However within institutions of learning, new challenges have been generated, one of which is the teaching and learning of ICT Related Courses (ICTRC) like Computer Science, Software Engineering, Computer Education, Computer Engineering Etc. Lately, in some institutions, there has been a decline in academic achievement scores of students taking ICTRC and low performance in
ICTRC at both the qualifying examination (SSCE) and placement examination like University Matriculation Examination - UME [2]. Some researchers confirm that there is also low enrolment for ICTRC, for students shun ICTRC as a discipline when given an option of courses to study in institutions.

Often times the teacher is blamed for the students' lack of interest in a course and poor performance. This is not farfetched because the teaching approach that a teacher adopts is a factor that affects students' perceptive power and performance in a course of study; however [8] and [3] postulated availability of teaching resources, capital resources, students attitude towards the teacher's teaching approach, the subject-matter and the teaching method as critical factors to the successful teaching and learning of ICTRC. Four factors critical to the effective learning of ICTRC in the classrooms and laboratories were identified by [4]: respondents' attitude, software selection, a proper utilization direction, and the capabilities of ICT professional educators.

There have been diverse research studies on students' effective learning of ICTRC. Reglin [11] studied the effects of teaching ICTRC on a sample of 53 minority prospective teachers, but focused on the issue of cooperativeness. A study conducted by [10] on a sample of 36 teachers centering on the use of ICT resources for ICT education based on knowledge acquisition. Another study by [7] focused on the educational use of ICT resources and students' performance while a research study by [5] compared the effectiveness of teaching agricultural science using ICT based learning against the regular teaching approach.

In this study, we posit that an ignored domain is the effect of gender as it affects single sex schools and coeducational schools. In the educational system, gender is taken into cognizance as it influences the curriculum, instructional materials, choice of career and general behavior of students and teachers alike. The relationship between gender and ICTRC is a vital area of research due to the fact that there are conflicting nature of results from researches that focus on gender and ICTRC.

The present study is interested in gender influence on the level of students' perception of teachers' effectiveness at teaching ICTRC and performance in ICTRC using ICT resources. Results from this study enable recommendations 
that promote ICT efficiency among students and lecturers in Nigeria and initiate some degree of resolution on the conflicting nature of learning ICTRC.

\section{STATEMENT OF THE PROBLEM}

In ascertaining the level of students' performance in ICTRC, some ignored domains are the effect of gender as it affects single sex schools and coeducational schools and students' perception of teachers' effectiveness. Thus presently, there is a dearth of information relating to the level of students' perception of teachers effectiveness in teaching and students performance in ICTRC using ICT resources within the classroom and laboratories gender composition. It becomes crucial to provide information relating to the effects of classroom gender composition, which enables the evaluation of the consequences of disparities of the sex ratios and the perception of students as regards lecturers' effectiveness in teaching ICTRC via ICT resources. It is strongly believed that this aforementioned will provide the optimum level of performance of ICTRC within the student population.

\section{OBJECTIVES OF THE STUDY}

The objectives of this study are:

- to compare the performance of male and female students taught ICTRC using ICT resources or the conventional lecture method.

- to investigate the effect of gender composition in students' performance in ICTRC when being taught with ICT resources or the conventional lecture method.

- to investigate students' perception of ICTRC taught by means of ICT resources as

\section{HYPOTHESIS}

The following null hypotheses were tested at 0.05 levels of significance:

- Ho: There is no significant difference in the performance of students taught ICTRC by means of ICT resources or the conventional lecture method.

- $\mathbf{H o}_{2}$ : There is no significant difference in the effect of gender composition in students' performance in ICTRC taught by means of ICT resources or the conventional lecture method.

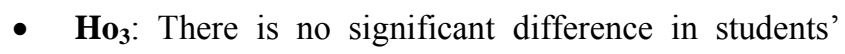
perception of ICTRC taught by means of ICT resources or the conventional lecture method.

\section{RESEARCH METHODOLOGY}

The study design employs a pre-test, post-test control group and quasi experimental design to determine the significant effect of ICT resources on students' performance in ICTRC. The following three variables were utilized in the study.

(1) Independent Variable:

a) Teaching via ICT resources

b) Conventional lecture method
(2) Dependent Variables:
a) Performance in ICTRC Test
b) Perception of ICTRC taught via ICT resources.

(3) Moderator Variables:

a) Gender (Male and Female)

\section{B. The Population And Sample}

The population of this study consisted of 248 randomly selected students offering ICTRC from university institutions in the South-South region of Nigeria. The stratified random sampling was used to select one Federal University (Uni-1) and one Private University (Uni-2) and to ensure evenness in institutions. Out of two institutions, some students were assigned as the experimental and control groups respectively.

\section{Instrumentation and Validation}

The following three instruments were designed and used for the study:

1) Instructional Plan for Teaching using Conventional Lecture Method (IPTCLM)

2) Instructional Plan for teaching using ICT Resources (IPITF).

3) Students' ICTRC Perception and Performance Test (SPPT).

a) Instructional Plan for teaching using Conventional Lecture Method (IPTCLM): To ensure consistency and uniformity, this teaching plan which involves teaching in the conventional lecture method, was used for all students in the control groups. It included the course objectives, instructional materials and teaching procedures of computer science concepts in the classroom. This plan was made available to teachers prior to the training sessions.

b) Instructional Plan for teaching using ICT Resources (IPITF): To ensure consistency and uniformity, this teaching plan includes subject area, objectives and the expected procedure to be followed by the teachers in the teaching of Computer Science concepts. This plan was made available to teachers prior to the training sessions and was used for all students in the experimental groups.

Students ICTRC Perception and Performance Test (SPPT): This instrument is divided into two sections designed by the researchers in the areas of Computer Science. The first section of the test was designed to cover the areas of perception which includes the areas of knowledge and comprehension. The section has 50 multiple choice objective items with options A to E designed to test the students' perception of computer science based on the methods (via ICT resources or lecture method) employed in inculcating the subject area to them. The second section consists of 50 questions to test the students' performance in computer science. The maximum obtainable score was 100 .

The face-validity and content-validity of the instruments was verified by three experts in the subject area. The instrument had a high Cronbach's alpha values, both for items within each subsection (range: 0.863 to 0.870 ) and for the instruments as a whole (0.951). 


\section{Data Collection Methods}

For two weeks, the researchers familiarize themselves with the students and the educational strategies to employ for the control and experimental groups using the IPTCLM and IPITF instruments. In the next two weeks, the pre-test was conducted and the instruments SPPT was administered to all the participating students to assess their initial performance level before the treatment effect would takes place. For four more weeks, the IPITF was administered to the experimental group who were taught using ICT resources. PowerPoint presentations and Video-clips were used to present animations techniques, animation concepts and constructive procedures. The video-clips include real life pictures of computer animations. These animations help to emphasize the critical points of computer science concepts that are employed in real settings that allow meaningful learning. Concurrently, the IPTCLM was used to teach the same concepts as that of the experimental group, only that in this case, the students were subjected to the conventional lecture method of teaching. For both groups, the researchers carried out the same activities. In the last week of the study, at two different instances, (one instance for an institution), the post-test was administered on all the participating students. The students were examined and their scripts were marked and results compiled.

\section{E. Method Of Data Analysis}

The post-test data on students' performance in ICTRC were analyzed using means and standard deviation. A five point Likert scale was used to measure all the statements on students perception of ICTRC taught by means of ICT resources or the conventional lecture method (Strongly Disagree (SRD), Disagree (D), Somewhat Disagree (SD), Neither Agree or Disagree (NAD), Somewhat Agree (SWA), Agree (A) and Strongly Agree (SA)).

\section{RESUltS AND DISCUSSIONS}

TABLE 1: Post-TeST Performance MEAn SCORE AND StandARD DEVIATION OF SPPT

\begin{tabular}{|c|c|c|c|c|c|}
\hline Variable & $\mathbf{N}$ & & $\mathbf{N}$ & Mean & Std. Dev. \\
\hline \multirow{6}{*}{ Experimental Group } & \multirow{3}{*}{ Uni-1 } & Male & 63 & 18.11 & 2.443 \\
\hline & & Female & 41 & 18.01 & 2.542 \\
\hline & & Total & 104 & 18.06 & 2.887 \\
\hline & \multirow{3}{*}{ Uni-2 } & Male & 08 & 17.41 & 1.662 \\
\hline & & Female & 05 & 17.33 & 2.221 \\
\hline & & Total & 13 & 17.37 & 2.237 \\
\hline \multirow{6}{*}{ Control Group } & \multirow{3}{*}{ Uni-1 } & Male & 73 & 17.40 & 2.114 \\
\hline & & Female & 45 & 16.10 & 2.213 \\
\hline & & Total & 118 & 16.75 & 2.225 \\
\hline & \multirow[t]{3}{*}{ Uni-2 } & Male & 07 & 16.71 & 1.996 \\
\hline & & Female & 06 & 16.09 & 2.117 \\
\hline & & Total & 13 & 16.40 & 2.113 \\
\hline \multirow{6}{*}{ Gender } & \multirow{3}{*}{ Uni-1 } & Male & 136 & 18.22 & 2.167 \\
\hline & & Female & 86 & 18.13 & 2.213 \\
\hline & & Total & 222 & 18.18 & 2.201 \\
\hline & \multirow[t]{3}{*}{ Uni-2 } & Male & 15 & 17.46 & 1.887 \\
\hline & & Female & 11 & 17.33 & 1.954 \\
\hline & & Total & 16 & 17.40 & 1.913 \\
\hline
\end{tabular}

The post-test mean score and standard deviation is shown in Table 1, which shows that Uni-1 students performed better than Uni-2 students. Generally, the experimental group who were being taught ICTRC with ICT resources performed better than students in the control group who were being taught using the conventional lecture method, therefore $\mathrm{Ho}_{1}$ is rejected. It is also evident that the male students performed better than the female students in each of the groups, thus $\mathrm{Ho}_{2}$ is rejected.

TABLE 2: EXPRESSIONS TO ESTABLISH STUDENTS' PERCEPTION OF ICTRC VIA ICT RESOURCES / LECTURE METHOD.

\begin{tabular}{|l|c|c|c|c|c|c|c|}
\hline \multicolumn{1}{|c}{ Questions } & SRD & D & SD & NAD & SWA & A & SA \\
\hline $\begin{array}{l}\text { It did not take } \\
\text { me long to } \\
\text { answer the } \\
\text { entire questions. }\end{array}$ & 4 & 2 & - & - & 1 & 8 & 16 \\
\hline $\begin{array}{l}\text { The manner of } \\
\text { teaching was } \\
\text { helpful }\end{array}$ & 3 & 1 & - & - & 1 & 7 & 19 \\
\hline $\begin{array}{l}\text { The allotted } \\
\text { time for the test } \\
\text { was too long }\end{array}$ & 3 & 1 & 1 & 2 & 3 & 5 & 16 \\
\hline $\begin{array}{l}\text { It was easy to } \\
\text { remember the } \\
\text { lesson taught }\end{array}$ & 4 & - & - & 1 & 2 & 6 & 18 \\
\hline $\begin{array}{l}\text { I think that the } \\
\text { lesson was very } \\
\text { well taught }\end{array}$ & - & 3 & 1 & - & 6 & 1 & 20 \\
\hline $\begin{array}{l}\text { My knowledge } \\
\text { on the subject } \\
\text { matter got better } \\
\text { with practice. }\end{array}$ & 3 & 4 & - & - & - & 2 & 22 \\
\hline $\begin{array}{l}\text { I understood the } \\
\text { entire lesson } \\
\text { taught }\end{array}$ & 15 & 8 & 1 & 1 & 1 & - & 5 \\
\hline $\begin{array}{l}\text { It was easy to } \\
\text { complete the } \\
\text { entire posttest } \\
\text { exercise. }\end{array}$ & 4 & 4 & - & - & 1 & 5 & 17 \\
\hline \multicolumn{1}{|c|}{ Total } & 36 & 23 & 3 & 4 & 15 & 34 & 133 \\
\hline
\end{tabular}

The students were asked the above eight questions to ascertain their perception of ICTRC taught by means of ICT resources or the conventional lecture method. The students' assessment is represented in Table 2. There was a significant difference on the eight questions as can be ascertained from the Chi-square analysis (Table 3).

TABLE 3: CHI-SQUARE ANALYSIS

\begin{tabular}{|c|c|c|c|c|c|}
\hline X & fo & fe & $\begin{array}{c}\text { (fo }- \\
\text { fe })\end{array}$ & $\begin{array}{c}\text { (fo }- \\
\text { fe })^{2}\end{array}$ & $\begin{array}{c}x^{2} \\
(\text { fo }- \text { fe })^{2} \\
\text { fe }\end{array}$ \\
\hline Strongly Disagree & 36 & 35.43 & 0.57 & 0.32 & 0.009 \\
\hline Disagree & 23 & 35.43 & -12.43 & 154.50 & 4.35 \\
\hline $\begin{array}{c}\text { Somewhat } \\
\text { Disagree }\end{array}$ & 3 & 35.43 & -32.43 & 1051.70 & 29.68 \\
\hline $\begin{array}{c}\text { Neither Agree or } \\
\text { Disagree }\end{array}$ & 4 & 35.43 & -31.43 & 987.84 & 27.88 \\
\hline Somewhat Agree & 15 & 35.43 & -20.43 & 417.38 & 11.78 \\
\hline Agree & 34 & 35.43 & -1.43 & 2.04 & 0.06 \\
\hline Strongly Agree & 133 & 35.43 & 97.57 & 9519.90 & 268.70 \\
\hline Total & $\mathbf{2 4 8}$ & $\mathbf{2 4 8}$ & & & $\mathbf{3 4 2 . 4 6}$ \\
\hline
\end{tabular}

$\mathrm{X}^{2}$ value $=342.46$

Degree of freedom $=7-1=6 ; \quad X^{2}$

at .99 at $4 d . f=16.812$

$X^{2}$ at .95 at 4 d. $f=12.592 ; \quad 342.46>16.812>12.592$ 
The Chi square analysis (Table 3) showed that the differences in perception are not due to chance. We can thus conclude that student' perception and understanding of ICTRC got better with practice, for all 20 students who acknowledged that the lesson was very well taught were those taught using ICT resources. It is also this class of students that accepted the fact that the subject matter got better with practice and that the manner of teaching was helpful.

\section{CONCLUSION}

Based on the findings in this study, it is evident that ICTbased resources and applications should drive the teachinglearning process of all ICTRC. Presently most educators adopt a theory-first approach and sometimes suspend teaching the application skills. For effective learning and performance, theory and applications should be interwoven and integrated. Or, at least, applications should be considered first, and then theory, to ensure that theory is related to real-world concepts and to enable students form conceptual relationships between theory and applications and create life-long learning experiences. Creating ICT-based case studies and interdisciplinary scenarios in ICTRC would also enable the students to solely define relevant concepts, identify theories and tools needed to solve conceptual problems, process data, report results, and providing all relevant documentation. To accomplish all the aforementioned and more, Departments within Faculties of ICTRC must work as a team. The team should discover, discuss and implement the interweaving of course materials.

\section{RECOMMENDATIONS}

The following recommendations were made based on the finding of the study:

- ICT teachers should use ICT resources in teaching ICTRC.

- ICT, IT and Science Faculties could collaborate to develop and teach courses for IT and its associated ICT.

- Seminars/worships should be organized for ICTRC teachers in school on the use of ICT resources.

- The government should set up laboratories and establish adequate ICT resources in all institutions of learning and make it possible for all disciplines to make use of it.

\section{REFERENCES}

[1] C. Adelman, "A Parallel Post-secondary Universe: The Certification System in Information Technology". (2000). Available at: http://www2.ed.gov/pubs/ParallelUniverse/universe.pdf

[2] D. Aduda, "Meeting gives Tips on How to Improve Science Subjects. The Daily Nation, Nairobi, Kenya": Nation Media group Ltd. September 2003, p.15.
[3] A. O. Egwali and V. V. N. Akwukwuma "Gender Inequality Issues in Educational Institutions: Goals for Millennium Development". Proceedings of the 2009 Third World Organization for Women in Science African Regional Conference, TWOWS' 09. November 16 - 20. (2009). Pg. 158 - 166. Abuja. Nigeria.

[4] D. J. Kadijevick, "Four critical issues of applying educational technology standards to professional development of ICT teachers". Proceedings of the 2nd International Conference on the Teaching of ICT at the Undergraduate Level, University of Crete. (2002).

[5] J. K. Kibett, \& N. J. Kathuri, "Effects of Projected- Based Learning on Student Performance in Secondary School Agriculture". Zimbabwe Journal of Educational Education, (2005). 37(1), 18-24.

[6] T. L. Larkin, "Learning style in the classroom: a research guided approach". Paper presented at the Annual Conference of International Conference on Engineering and Computer Education, March 16 - 19, 2003, Sao Paulo, Brazil.

[7] E. Leuven, M. Indahl, H. Oosterbeek, and D. Webbink, "The Effect of Extra Funding for Disadvantaged Pupils on Achievement". IZA Discussion Paper. No. 1122. Bonn: Institute for the Study of Labor. (2004).

[8] H. R. Mills, "Teaching and Training": A handbook for instructors (3rd ed). London: Macmillan Publishers. (1991).

[9] O. Minishi, E. Muni, O. Okumu P. Mutai, G. Mwangasha, H. Omolo \& F. Munyeke, "Secondary Physics Form One" 3rd ed. Kenya Literature Bureau. Nairobi. (2004).

[10] J., Moor, \& R. Zazkis, "Learning ICT in a virtual classroom: Reflection on experiment". Journal of Computers in ICT and Science Teaching, (2000). 19 (2), 89-113.

[11] G. L. Reglin, "The effects of individualized and cooperative computer assisted instruction on ICT achievement and ICT anxiety for prospective teachers". Journal of Research on Computing in Education, (1990). 22 (2), 404-413.

\section{AUTHORS PROFILE}

Dr. (Mrs) Egwali Annie Ogheneruke, is presently a Senior Lecturer in the Department of Computer Science, Faculty of Physical Sciences, University of Benin. Nigeria. She obtained her B.Sc. degree in Computer Science in 1995 from the University of Benin, M.Sc. degree in Computer Science in 2001 from the University of Benin and $\mathrm{PhD}$ in degree in Computer Science in 2010 from the University of Benin. She lectured in the College of Education, Ekiadolor Benin for eight years during she engaged in various administrative and charitable functions. Her area of interests includes Information Technology, Software Engineering, Gender studies, E-commerce, Electronic Marketing and Software Security. To date, she has supervised several diploma, undergraduate and postgraduate students. She is a member of International Network for Women Engineers and Scientists (INWES), Nigerian Computer Society (NCS), Nigerian Association of Educationists for National Development (NAEND, National Association for the Advancement of Knowledge (NAFAK) and Third World Organizations of Women Scientists (TWOWS).

Igodan Charles Efosa, is currently a lecturer in the Department of Computer Science, University of Benin, Edo State, Nigeria. He obtained his B.Sc. degree in Computer Science in 2004 from University of Benin (UNIBEN) and M.Tech degree in Computer Science in 2012 from Federal University of Technology, Akure, Nigeria. He has worked as system engineer/consultant for 4years with NetCom Tech. Consortium and programme analyst in the University of Benin Teaching Hospital (UBTH) for 4years during which he has been teaching in various institutions. His interests are in Data mining, knowledge warehousing, expert system, information systems and databases. 